С. В. Авдєєв, Ю. К. Змарко, А. Б. Бойків, Р. О. Древніцька

ДВНЗ «Тернопільський державний медичний університет імені І. Я. Горбачевського»

\title{
Вплив лікувально-профілактичних заходів на показники ротової рідини та клінічний стан тканин пародонта у дітей 6-7 років, хворих на гінгівіт
}

Резюме. Висока поширеність запальних процесів у пародонті дітей, недостатня ефективність профілактичних і лікувальних заходів можуть сприяти розвитку генералізованого пародонтиту, тому актуальним залишається розробка патогенетичного впливу при лікуванні хронічного катарального гінгівіту.

Мета дослідження - порівняльна оцінка традиційного лікування хронічного катарального гінгівіту в дітей 6-7 років з терапією із використанням протизапального гелю з неовітином.

Матеріали і методи. 61 дитину віком 6-7 років, хвору на хронічний катаральний гінгівіт, було взято під диспансерне спостереження та поділено на групи: основну (30 дітей) і порівняльну (31 дитина). Усім дітям проводили загальноприйняту терапію згідно з протоколами надання медичної допомоги базова терапія. В основній групі протягом місяця застосовували засоби патогенетичної спрямованості - протизапальний гель із неовітином, рекомендовані засоби гігієни. В порівняльній групі для місцевої терапії було використано 3 \% розчин пероксиду водню; для полоскань ротової порожнини (протягом першого тижня лікування) - «Ротокан», лікувально-профілактична зубна паста. Обстеження та контрольні огляди проводили із визначенням гігієнічного стану порожнини рота за гігієнічним індексом Ю. А. Федорова і В. В. Володкіної, поширеності та інтенсивності запального процесу в яснах за допомогою проби Шиллера-Писарєва та індексу РМА, показників ротової рідини (вміст лізоциму, утворення оксидрадикалів, уреазної активності, ступеня дисбіозу, рН та в’язкості).

Результати досліджень та їх обговорення. Після проведеного лікування ліквідація процесу запалення ясен у хворих основної групи супроводжувалась зменшенням індексу РМА у 3,8 раза; утворення оксирадикалів знизилося у дітей основної групи на 6,35 \%; у порівняльній групі - на 6,15 \%. Уреазна активність зменшилася у дітей основної групи на $16,37 \%$ (р<0,05); в’язкість ротової рідини знижувалася у 2,65 раза в основній групі та у 2,13 раза - у порівняльній $(p<0,05)$. Вміст лізоциму збільшився у дітей основної групи на 15,61 \% (p<0,05); водночас, у порівняльній групі - лише на 9,63 \% $(\mathrm{p}<0,05)$. Проведене лікування через 0,5 року викликало зростання вмісту лізоциму в ротовій рідині дітей основної групи до рівня показника контрольної групи. Ступінь дисбіозу зменшувався в основній групі, в порівняльній мав тенденцію до збільшення.

Висновки. Застосування запропонованої терапії із використанням гелю з неовітином сприяло кращим результатам лікування: зменшенню ступеня запалення ясен, кількості відвідувань лікаря, покращенню показників неспецифічного захисту в ротовій рідині дітей 6-7 років, причому більшою мірою через півроку після проведеного лікування.

Ключові слова: діти 6-7 років; хронічний катаральний гінгівіт; неспецифічний захист; лікування.

\section{(СА. В. Авдеев, Ю. К. Змарко, А. Б. Бойкив, Р. А. Древницкая}

гВУз «Тернопольский государственный медицинский университет имени И. Я. Горбачевского»

\section{Воздействие лечебно-профилактических мероприятий на показатели ротовой жидкости и клиническое состояние тканей пародонта у детей 6-7 лет, больных гингивитом}

Резюме. Высокая распространенность воспалительных процессов в пародонте детей, недостаточная эффективность профилактических и лечебных мероприятий могут способствовать развитию генерализованного пародонтита, поэтому актуальным остается разработка патогенетического воздействия при лечении хронического катарального гингивита.

Цель исследования - сравнительная оценка традиционного лечения хронического катарального гингивита у детей 6-7 лет с терапией с использованием противовоспалительного геля с неовитином. 
Материалы и методы. 61 ребенка в возрасте 6-7 лет, больного хроническим катаральным гингивитом, было взято под диспансерное наблюдение и разделено на группы: основную (30 детей) и сравнительную (31 ребенок). Всем детям проводилась общепринятая терапия в соответствии с протоколами оказания медицинской помощи - базовая терапия. В основной группе в течение месяца применяли средства патогенетической направленности - противовоспалительный гель с неовитином, рекомендованы средства гигиены. В сравнительной группе для местной терапии был использован 3 \% раствор перекиси водорода, для полосканий полости рта (в течение первой недели лечения) - «Ротокан», лечебно-профилактическая зубная паста. Обследование и контрольные осмотры проводили с определением гигиенического состояния полости рта гигиеническим индексом Ю. А. Федорова и В. В. Володкиной, распространенности и интенсивности воспалительного процесса в деснах с помощью пробы Шиллера-Писарева и индекса РМА, показателей ротовой жидкости (содержание лизоцима, образования оксидрадикалов, уреазной активности, степени дисбиоза, рН и вязкости).

Результаты исследований и их обсуждение. После проведенного лечения ликвидация процесса воспаления десен у больных основной группы сопровождалась уменьшением индекса РМА в 3,8 раза; образования оксирадикалов уменьшилось у детей основной группы на 6,35 \%; в сравнительной группе на 6,15 \%. Уреазная активность уменьшилась у детей основной группы на 16,37 \% (p<0,05), вязкость ротовой жидкости - в 2,65 раза в основной группе и в 2,13 раза - в сравнительной ( $<<0,05)$, Содержание лизоцима увеличилось у детей основной группы на 15,61\% (p<0,05) в группе сравнения - на 9,63 \% $(\mathrm{p}<0,05)$. Проведенное лечение через 0,5 года вызвало увеличение содержания лизоцима в ротовой жидкости детей основной группы до уровня показателя контрольной группы. Степень дисбиоза уменьшилась в основной группе, в группе сравнения имела тенденцию к увеличению.

Выводы. Применение предложенной терапии с использованием геля с неовитином способствовало лучшим результатам лечения: уменьшению степени воспаления десен, количества посещений врача, улучшению показателей неспецифической защиты в ротовой жидкости детей 6-7 лет, причем в большей степени через полгода после проведенного лечения.

Ключевые слова: дети 6-7 лет; хронический катаральный гингивит; неспецифическая защита; лечение.

CO. V. Avdeev, Y. K. Zmarko, A. B. Boykiv, R. O. Drevnitska

I. Horbachevsky Ternopil State Medical University

\section{The effect of therapeutic and prophylactic measures in oral fluid parameters and the clinical condition of periodontal tissues in children 6-7 years suffering from gingivitis}

Summary. The high prevalence of inflammatory processes in the periodontitis of children, the ineffective effectiveness of preventive and curative measures can contribute to the development of generalized periodontitis, therefore it remains urgent to develop pathogenetic effects in the treatment of chronic catarrhal gingivitis.

The aim of the study - a comparative assessment of the traditional treatment of chronic catarrhal gingivitis in children aged 6-7 years with therapy using an anti-inflammatory gel with neovitin.

Materials and Methods. 61 children aged 6-7 years, suffering from chronic catarrhal gingivitis, were taken under clinical supervision and divided into groups: the main (30 children) and the comparative (31 children). All children underwent conventional therapy in accordance with the protocols for the provision of medical care - basic therapy. In the main group, for a month, pathogenetic agents were used: an anti-inflammatory gel with neovitin, hygiene products were recommended. In the comparative group, $3 \%$ hydrogen peroxide solution was used for local therapy, for rinsing of the mouth (during the first week of treatment) - Rotokan, a therapeutic and prophylactic toothpaste.

Examination and control examinations were carried out with the hygienic state of the mouth determined by the hygienic index of Yu. A. Fedorov and V. V. Volodkina, prevalence and intensity of the inflammatory process in the gums with the help of the Schiller-Pisarev test and the PMA index, oral fluid index (lysozyme content, formation of oxydradicals, urease activity, degree of dysbiosis, $\mathrm{pH}$ and viscosity).

Results and Discussion. After the treatment, elimination of gum inflammation in patients of the main group was accompanied by a decrease in the PMA index by 3.8 times; formation of oxyradicals decreased in children of the main group by $6.35 \%$; in the comparative group - by $6.15 \%$. Urease activity decreased in children of the main group by $16.37 \%(\mathrm{p}<0.05)$, the viscosity of the oral fluid of children decreased in 2.65 times in the main group and in 2.13 times in the comparative group $(\mathrm{p}<0.05)$. The lysozyme content increased in children of the 


\section{Дитяча стоматологія}

main group by $15.61 \%(\mathrm{p}<0.05)$ in the comparison group - by $9.63 \%(\mathrm{p}<0.05)$. The treatment after 0.5 years caused an increase in the lysozyme content in the oral fluid of the children of the main group to the level of the control group. The degree of dysbiosis decreased in the main group, in the comparison group tended to increase.

Conclusions. The use of the proposed therapy with gel with neovitin contributed to the best results of treatment: reducing the degree of inflammation of the gums, the number of visits to the doctor, improving the indices of nonspecific protection in the oral fluid of 6-7 years-old children and, to a greater extent, six months after the treatment.

Key words: 6-7 year-old children; chronic catarrhal gingivitis; nonspecific protection; treatment.

Вступ. Публікації авторів за останні роки засвідчують, що вже у дитячому віці поширеність гінгівіту сягає 80-95 \% без тенденції до зниження [1]. На поширення запальних захворювань тканин пародонта у дітей впливає погіршення стану довкілля в Україні, зниження рівня життя населення 3 відповідним погіршенням якості харчування та зменшенням витрат на якісні засоби догляду за порожниною рота і т.д. Разом із тим, неефективне лікування запальних захворювань пародонта призводить до частого рецидивування, переходу запального процесу з ясен на кісткову тканину альвеолярного відростка 3 руйнуванням опорно-утримувальних тканин зуба 3 наступною їх втратою. Водночас, якісне лікування гінгівіту в дітей є запорукою реституції структури і функцій тканин пародонта.

На сьогодні загальновизнаними показниками, що дозволяють оцінити ушкодження пародонта, $є$ активність пероксидного окиснення ліпідів та антиоксидантного захисту [2], які в нормі виконують фізіологічну функцію оновлення старих і зруйнованих структур клітин.

Достатню кількість наукових робіт присвячено вивченню впливу різнорідних чинників на розвиток і перебіг гінгівіту, пропонують ряд методів лікування з включенням у комплексне лікування препаратів різних груп $[3,4]$. Водночас, ураховуючи високу поширеність запальних процесів у пародонті дітей, слід зробити висновок про недостатню ефективність профілактичних і лікувальних заходів. Експериментальні дослідження [5, 6], раніше проведені, дозволяють віддати перевагу в лікуванні гінгівіту препаратам, що зменшують патогенетичний вплив антигенного навантаження на тканини пародонта шляхом зниження сенсибілізації, стимуляції адаптаційної спроможності організму [7], зокрема протизапальному гелю з неовітином (VIVAX Dent).

Мета дослідження - порівняльна оцінка традиційного лікування хронічного катараль- ного гінгівіту в дітей 6-7 років із терапією 3 використанням протизапального гелю 3 неовітином.

Матеріали і методи. У ЗОШ Тернополя та на клінічній базі кафедри дитячої стоматології ДВНЗ «Тернопільський державний медичний університет імені I. Я. Горбачевського МОЗ України» було проведено обстеження 94 дітей 6-7 років, що включало визначення пародонтологічного статусу, рівня гігієни та нозологічної форми захворювання [1]. Проведене дослідження виявило у 61 (64,9 \%) дитини хронічний катаральний гінгівіт. Для визначення найефективнішого лікування і профілактики загострень хронічного катарального гінгівіту хворих дітей взяли під диспансерне спостереження та випадково поділили на групи: основну (30 дітей) і порівняльну (31 дитина). Усім дітям проводили загальноприйняту терапію згідно з протоколами надання медичної допомоги - базова терапія. В обох групах лікуванню передувало проведення гігієнічного навчання, професійна гігієна порожнини рота, лікування карієсу зубів. В основній групі протягом місяця застосовували засоби патогенетичної спрямованості - протизапальний гель 3 неовітином - проводили аплікації на ясна (у вихідні дні, згідно 3 інструкцією щодо використання, рекомендували додавати 1 мл гелю в зубну пасту прямо на зубну щітку). При чищенні зубів пропонували застосовувати зубну пасту «VIVAX Dent з активним пептидним комплексом і бетулавітом» протягом 4 тижнів, потім протягом 4 тижнів - зубну пасту «VIVAX Dent 3 активним пептидним комплексом і бісабололом». Такий лікувально-профілактичний курс проводили 2 рази в рік (навесні та восени).

У порівняльній групі для місцевої терапії використали 3 \% розчин пероксиду водню; для полоскань ротової порожнини (протягом першого тижня лікування) - «Ротокан», лікувально-профілактичну зубну пасту. 
Контрольні огляди та обстеження із визначенням гігієнічного стану порожнини рота за гігієнічним індексом Ю. А. Федорова і В. В. Володкіної [8], поширеності та інтенсивності запального процесу в яснах оцінювали за допомогою проби Шиллера-Писарєва та індексу PМА [9], показників ротової рідини (pH і в'язкість [9], утворення оксидрадикалів [10], уреазна активність [11], вміст лізоциму [12]) в дітей обох груп проводили після закінчення лікування та через 6 місяців; за необхідності (рецидив захворювання) - курс лікування повторювали.

Контрольні величини досліджуваних показників ротової рідини було отримано після обстеження 20 дітей 6-7 років, які не увійшли в групи клінічних спостережень, не мали запальних явищ у яснах та мали сановані зуби.

Статистичну обробку результатів проведено за допомогою програм Microsoft Exel i Statistica-6,0. Вірогідність відмінностей середніх величин визначали за допомогою критерію Стьюдента.
Результати досліджень та їх обговорення. У дітей досліджуваних груп під час обстеження до лікування стан тканин пародонта та гігієни не мали вірогідних відмінностей за всіма параклінічними параметрами. Клінічні спостереження під час лікування продемонстрували, що у дітей основної групи на 2-3 добу визначалося зниження ознак запалення ясен у 25 пролікованих (83,3 \%): слизова оболонка набувала блідорожевого кольору, зникали набряк і кровоточивість, ясна щільно охоплювали шийки зубів, значно зменшувалася кількість зубних нашарувань. У групі порівняння, де дітям проводили традиційне лікування, зменшення ознак запалення визначили на 4-5 добу в 20 хворих (64,5 \%).

Динамічне спостереження та контрольний огляд дітей груп спостережень через 0,5 року iз визначенням параклінічних показників показав кращі результати лікування у дітей основної групи після запропонованої нами терапії. Показники дітей основної групи достовірно відрізнялись від показників дітей порівняльної групи (табл. 1).

таблиця 1. Динаміка параклінічних показників у дітей, хворих на гінгівіт, віком 6-7 років $(\mathrm{M} \pm \mathrm{m})$

\begin{tabular}{|c|c|c|c|c|}
\hline \multirow{2}{*}{$\begin{array}{l}\text { Термін } \\
\text { лікування }\end{array}$} & \multirow{2}{*}{$\begin{array}{c}\text { Група } \\
\text { спостереження }\end{array}$} & \multicolumn{3}{|c|}{ Параклінічний показник } \\
\hline & & $\begin{array}{c}\text { проба Шиллера- } \\
\text { Писарєва } \\
\end{array}$ & індекс РМА, \% & $\begin{array}{c}\text { індекс Федорова- } \\
\text { Володкіної (ГІ) }\end{array}$ \\
\hline \multirow[t]{2}{*}{ До лікування } & $\begin{array}{l}\text { основна, } \\
n=30\end{array}$ & позитивна & $30,1 \pm 3,62$ & $2,08 \pm 0,06$ \\
\hline & $\begin{array}{l}\text { порівняльна, } \\
\text { n=31 }\end{array}$ & позитивна & $30,3 \pm 4,06$ & $1,99 \pm 0,08$ \\
\hline \multirow[t]{2}{*}{ Після лікування } & $\begin{array}{l}\text { основна, } \\
n=30\end{array}$ & негативна & $6,7 \pm 0,72 * / * *$ & $0,75 \pm 0,02 * / * *$ \\
\hline & $\begin{array}{l}\text { порівняльна, } \\
\text { n=31 }\end{array}$ & негативна & $10,2 \pm 0,88^{*}$ & $0,93 \pm 0,03^{*}$ \\
\hline \multirow[t]{2}{*}{$\begin{array}{l}\text { Через } 6 \text { місяців } \\
\text { після лікування }\end{array}$} & $\begin{array}{l}\text { основна, } \\
n=30\end{array}$ & негативна & $7,9 \pm 1,24 * / * *$ & $1,05 \pm 0,02 * / * *$ \\
\hline & $\begin{array}{l}\text { порівняльна, } \\
\text { n=31 }\end{array}$ & $\begin{array}{l}\text { від негативної до } \\
\text { слабопозитивної }\end{array}$ & $16,1 \pm 0,98^{*}$ & $1,43 \pm 0,03^{*}$ \\
\hline
\end{tabular}

Примітки: 1) * - різниця даних достовірна порівняно з показником до лікування, $\mathbf{p}<0,05$;

2) ** - різниця даних достовірна порівняно з показником групи порівняння, $\mathrm{p}<0,05$.

Після проведеного лікування ліквідація процесу запалення ясен у хворих основної групи супроводжувалась зменшенням індексу РМА у 4,5 раза, ГІ - в 2,8 раза; в групі порівняння у 2,9 і 2,1 раза відповідно. Встановлено скорочення терміну лікування дітей при застосуванні запропонованої лікувальної схеми: 3-4 відвідування (в середньому 3,5) в основній групі та 4-5 відвідувань (у середньому 4,5) в групі порівняння $(\mathrm{p}<0,05)$.
У дітей основної групи через 6 місяців після лікування індекс РМА збільшився, але залишався достовірно меншим у 3,8 раза, ніж до лікування, в групі порівняння - 1,9 раза. Гігієнічний індекс за Федоровим-Володкіною (ГІ) погіршився на 40 \% і був меншим від показника до лікування у 1,9 раза в основній групі; у групі порівняння на 53,8 \% та у 1,4 раза відповідно. У дітей основної групи проба ШиллераПисарєва після лікування та через 6 місяців 


\section{Дитяча стоматологія}

була від’ємною, не проявляючи забарвлення ясен.

Динаміку показників ротової рідини представлено у таблиці 2. До лікування достовірної різниці між показниками основної і по- рівняльної груп не було. Водночас, наявність хронічного запального процесу в яснах дітей сприяла зменшенню у ротовій рідині вмісту лізоциму в 1,2 раза ( $<0,05)$, також достовірно зменшувався рН.

Таблищя 2. Динаміка показників ротової рідини дітей 6-7 років груп спостережень (M $\pm \mathrm{m})$

\begin{tabular}{|c|c|c|c|c|c|c|}
\hline Група & \begin{tabular}{|c|} 
Утворення \\
оксирадика- \\
лів, УОФ/мл \\
слини \\
\end{tabular} & $\begin{array}{c}\text { Уреазна } \\
\text { активність, } \\
\mathrm{N}-\mathrm{NH}_{4}{ }^{+} \mathrm{Mr} / \mathrm{M \Gamma}^{-1} \\
\text { білка }\end{array}$ & $\mathrm{pH}$ & $\begin{array}{l}\text { В'язкість, } \\
\text { пуаз }\end{array}$ & $\begin{array}{c}\text { Вміст лізоциму, } \\
\text { мг/л }\end{array}$ & $\begin{array}{c}\text { Ступінь } \\
\text { дисбіозу } \\
\text { (уреаза/лізо- } \\
\text { цим)×100 }\end{array}$ \\
\hline $\begin{array}{l}\text { Контроль- } \\
\text { на, } \mathrm{n}=20\end{array}$ & $51,59 \pm 2,15$ & $1,09 \pm 0,14$ & $8,02 \pm 0,04$ & $1,49 \pm 0,13$ & $155,78 \pm 3,58$ & $0,71 \pm 0,11$ \\
\hline $\begin{array}{l}\text { Основна до } \\
\text { лікування, } \\
\text { n=30 }\end{array}$ & $58,74 \pm 1,34^{*}$ & $1,71 \pm 0,15^{*}$ & $7,80 \pm 0,05^{*}$ & $5,78 \pm 0,11^{*}$ & $130,02 \pm 0,98^{*}$ & $1,34 \pm 0,10^{*}$ \\
\hline $\begin{array}{l}\text { Порів- } \\
\text { няльна до } \\
\text { лікування, } \\
(\mathrm{n}=31)\end{array}$ & $59,23 \pm 1,59 *$ & $1,72 \pm 0,13^{*}$ & $7,84 \pm 0,07^{*}$ & $5,80 \pm 0,14^{*}$ & $128,32 \pm 1,08^{*}$ & $1,35 \pm 0,11^{*}$ \\
\hline $\begin{array}{l}\text { Основна } \\
\text { після } \\
\text { лікування, } \\
\text { n=30 } \\
\end{array}$ & $55,01 \pm 1,24^{* *}$ & $1,43 \pm 0,04^{* *}, * * *$ & $8,00 \pm 0,03^{* *}$ & $2,18 \pm 0,13^{* *}$ & $150,32 \pm 2,78^{* * * * * *}$ & $0,95 \pm 0,04^{* *}, * * *$ \\
\hline $\begin{array}{l}\text { Порівняль- } \\
\text { на після } \\
\text { лікування, } \\
\text { n=31 }\end{array}$ & $55,59 \pm 1,10$ & $1,57 \pm 0,02$ & $7,72 \pm 0,06$ & $2,72 \pm 0,34^{* *}$ & $140,68 \pm 1,29 * *$ & $1,11 \pm 0,02^{* *}$ \\
\hline $\begin{array}{l}\text { Основна че- } \\
\text { рез } 0,5 \text { року, } \\
n=30\end{array}$ & $53,00 \pm 2,10^{* *}$ & $1,35 \pm 0,05^{* *}, * * *$ & $8,00 \pm 0,05^{* *}, * * *$ & $2,10 \pm 0,11^{* *}, * * *$ & $155,60 \pm 3,69 * *, * * *$ & $0,87 \pm 0,04^{* *}, * * *$ \\
\hline $\begin{array}{l}\text { Порівняль- } \\
\text { на через } \\
0,5 \text { року, n=31 }\end{array}$ & $54,99 \pm 0,95^{* *}$ & $1,57 \pm 0,03$ & $7,74 \pm 0,05$ & $2,50 \pm 0,09$ & $140,96 \pm 1,24$ & $1,12 \pm 0,03$ \\
\hline
\end{tabular}

Примітки: 1) * - відмінність достовірна від показника контрольної групи;

2) ** - відмінність достовірна від показника порівняльної групи до лікування;

3) *** - відмінність достовірна від показника порівняльної групи відповідного терміну спостереження.

Відбувалося збільшення утворення оксирадикалів від показника контрольної групи на 14,81 і 13,86 \%; уреазної активності - на 57,79 i 56,88 \% та ступеня дисбіозу - на 90,14 і 88,73 \% у основній і порівняльній групах відповідно.

Ефективність проведеного лікування підтвердили зміни досліджуваних показників. Так, утворення оксирадикалів зменшилося у дітей основної групи на 6,35 \%; у порівняльній групі - на 6,15 \%. Уреазна активність зменшилася у дітей основної групи на 16,37 \%, причому різниця від показника порівняльної групи до лікування була достовірною $(\mathrm{p}<0,05)$; зменшення цього показника у порівняльній групі склало 8,72 \%. Коливання $\mathrm{pH}$ залишалися у межах фізіологічної норми. В'язкість ротової рідини дітей зменшувалася у 2,65 раза в основній групі та у 2,13 раза - у порівняльній $(\mathrm{p}<0,05)$. Вміст лізоциму збільшився у дітей основної групи на 15,61 \% ( $<0,05)$; водночас, у порівняльній групі - лише на 9,63 \% (p<0,05). Проведене лікування викликало зменшення ступеня дисбіозу в основній групі у 1,41 раза $(\mathrm{p}<0,05)$, в порівняльній - у 1,22 раза $(\mathrm{p}<0,05)$.

Цікавим виявилося порівняння показників ротової рідини дітей через 0,5 року. Зокрема, утворення оксирадикалів у основній групі достовірно $(\mathrm{p}<0,05)$ було меншим як від по- 
казника порівняльної групи до лікування (на 9,77 \%), так і від показника порівняльної групи через 0,5 року (на 3,76 \%) та достовірно не відрізнялося від показника дітей контрольної групи. Також достовірною була різниця між уреазною активністю у дітей основної і порівняльної груп - на 16,29 \%. Окрім того, вміст лізоциму в основній групі зріс і досягнув показника контрольної групи; у порівняльній групі цей показник практично не змінився. Водночас, ступінь дисбіозу зменшувався в основній групі, в порівняльній мав тенденцію до збільшення.

Таким чином, можна стверджувати, що запропонована схема лікування за показниками ротової рідини давала кращі результати як одразу після лікування, так і сприяла їх подальшому покращенню через 0,5 року. Все це свідчить, що довготривалий ефект проведеної терапії пов’язаний із впливом на патогенез за-

\section{Список літератури}

1. Терапевтическая стоматология детского возраста / [Хоменко Л. А., Кисельникова Л. П., Смоляр Н. И. и др.]. - К. : Книга плюс, 2007. - 864 с.

2. Воскресенский О. Н. Роль перекисного окисления липидов в патогенезе пародонтита / О. Н. Воскресенский, Е. К. Ткаченко // Стоматология. - 1991. № 4. - С. 5-10.

3. Богданова В. О. Клинические возможности использования метаболитов микрофлоры в диагностике и лечении воспалительных заболеваний пародонта / В. О. Богданова, В. В. Свирин, М. Д. Ардатская // Стоматология для всех. - 2009. - № 4 - С. 46-50.

4. Волченко Н. В. Влияние комплексной профилактики на уровень биохимических маркеров воспаления и дисбиоза в слюне детей с разным типом школьного обучения / Н. В. Волченко, И. И Соколова // Вісник стоматології. - 2014. - № 1. - С. 66-69.

5. Змарко Ю. К. Ступінь активності кислої фосфатази при експериментальному гінгівіті та за його корекції / Ю. К. Змарко, О. В. Авдєєв // Здобутки клінічної і експериментальної медицини. - 2014. № 1 (20). - С. 48-50.

6. Змарко Ю. К. Зміни активності лужної фосфатази при експериментальному гінгівіті та за його корек-

\section{REFERENCES}

1. Khomenko, L.A., Riselnikova, L.P., Smoliar, N.I., \& Chaykovskyy, Yu.B. (2007). Terapevtycheskaya stomatologiya detskogo vozrasta [Therapeutic dentistry of childhood] Kyiv: Knyha plius [in Russian].

2. Voskresenskyi, O.N., \& Tkachenko, E.K. (1991). Rol perekysnogo okyslenyia lipidov v patogeneze parodontita [Role of peroxide oxidation of lipids in the pathogenesis of periodontitis]. Stomatologiya - Stomatology, 4, 5-10 [in Russian]. палення у яснах, тому відбувалося зменшення ступеня дисбіозу зі збільшенням терміну спостереження.

Висновки. Результати досліджень, проведених нами, показали, що застосування запропонованої терапії із використанням гелю 3 неовітином сприяло кращим результатам лікування: зниженню ступеня запалення ясен за індексом РМА у 3,8 раза, зменшенню ступеня дисбіозу та кількості відвідувань лікаря на одне відвідування, збільшенню показників неспецифічного захисту в ротовій рідині дітей, причому більшою мірою через півроку після проведеного лікування.

Перспективи подальших досліджень полягають у проведенні досліджень рівня неспецифічного захисту та ступеня дисбіозу в ротовій рідині дітей старшого шкільного віку (16-17 років), хворих на хронічний катаральний гінгівіт, із використанням різних лікувальних схем.

ції / Ю. К. Змарко, О. В. Авдєєв // Український медичний альманах. - 2014. - Т. 17, № 2. - С. 32-33.

7. Хавинсон В. Х. Пептидная регуляция основных функций организма / В. Х. Хавинсон, Г. А. Рыжак // Вестник Росздравнадзора. - 2010 - № 6. - С. 58-62.

8. Федоров Ю. А. Оценка очищающего действия зубных гигиенических средств и качества ухода за полостью рта / Ю. А. Федоров, В. В. Володкина // Терапевтическая и ортопедическая стоматология. К. : Здоров'я, 1971. - Вып. 1. - С. 117-119.

9. Заболотний Т. Д. Запальні захворювання пародонта / Т. Д. Заболотний, А. В. Борисенко, Т. І. Пупін Львів : ГалДент, 2013. - 233 с.

10. Role of metallothionein against oxidative stress in the mussel Mytilus galloprovincialis / A. Viarengo, B. Burlando, M. Cavaletto [et. al.] // Am. J. Physiol. Regul. Integr. Comp. Physiol. - 1999. - Vol. 277. - P. R1612R1619.

11. The relationship between dental caries status and dental plaque urease activity / M. Shu., E. MorouBermudez, E. Suárez-Pérez [et al.] // Oral Microbiology and Immunology. - 2007. - Vol. 22(1). - P. 61-66.

12. Дорофейчук В. Г. Определение активности лизоцима нефелометрическим методом / В. Г. Дорофейчук // Лабораторное дело. - 1968. - № 1. - С. 28-30.

3. Bohdanova, V.O., Svyryn, V.V., \& Ardatskaya, M.D. (2009). Klinicheskie vozmozhnosti ispolzovaniya metabolitov mikroflory $\mathrm{v}$ diagnostike s lechenii vospalytelnykh zabolevaniy parodonta [Clinical possibilities of using metabolites of microflora in the diagnosis and treatment of inflammatory periodontal diseases]. Stomatologiya dlya vsekh - Stomatologiyya for All, 4, 46-50 [in Russian]. 


\section{Дитяча стоматологія}

4. Volchenko, N.V., \& Sokolova I.I. (2014). Vliyanye kompleksnoy profylaktiky na uroven bookhimicheskykh markerov vospaleniya i disbioza $\mathrm{v}$ slyune detey $\mathrm{s}$ raznym tipom shkolnogo obucheniya [Influence of complex preventive on the level of biochemical markers of inflammation and dysbiosis in saliva of children with different type of school education]. Visnyk stomatolohiiJournal of Stomatology, 1, 66-69 [in Russian].

5. Zmarko, Yu.K. \& Avdieiev, O.V. Stupin aktyvnosti kysloi fosfatazy pry eksperymentalnomu hinhiviti ta za yoho korektsii [Activity level of acid phosphatase when experimental gingivitis and its correction]. Zdobutky klinichnoi i eksperymentalnoi medytsyny - Achievements of clinical and experimental medicine, 1, (20), 48-50 [in Ukrainian].

6. Zmarko, Yu.K., \& Avdieiev, O.V. (2014). Zminy aktyvnosti luzhnoi fosfatazy pry eksperymentalnomu hinhiviti ta za yoho korektsii [Changes of activity of alkaline phosphatase when experimental gingivitis and its correction]. Ukrayinskyi medychnyi almanakh, 17, (2), 32-33 [in Ukrainian].

7. Khavynson, V.Kh. \& Ryzhak H.A. (2010). Peptydnaya regulyatsyya osnovnykh funktsyy organizma [Peptide regulation of the main boby functions]. Vestnyk Ros- zdravnadzora - Journal of Roszdravnadzor, 6, 58-62 [in Russian].

8. Fedorov, Yu.A. \& Volodkyna V.V. (1971). Otsenka ochyshchayushchego deystviya zubnykh gigienicheskykh sredstv i kachestva ukhoda za polostyu rta [Assessment of cleaning effect of tooth hygienic means and quality of oral cavity care]. Terapevtycheskaya i ortopedycheskaya stomatologiya. - Kyiv: Zdorovia [in Russian].

9. Zabolotnyi T.D., Borysenko, A.V., \& Pupin T.I. (2013). Zapalni zakhvoriuvannia parodonta [Paradontium inflammatory diseases]. Lviv: HalDent [in Ukrainian]. 10. Viarengo, A., Burlando, B., \& Cavaletto, M. (1999). Role of metallothionein against oxidative stress in the mussel Mytilus galloprovincialis. Am. J. Physiol. Regul. Integr. Comp. Physiol. 277, R1612-R1619.

11. Shu., M., Morou-Bermudez, E., \& Suárez-Pérez E. (2007). The relationship between dental caries status and dental plaque urease activity. Oral. Microbiology and Immunology, 22 (1), 61-66 .

12. Dorofeychuk, V.G. (1968). Opredeleniye aktivnosti lizotsima nefelometricheskim metodom [Determination of lisolyne activity by nephelometric method]. Laboratornoye delo - Laboratory case, 1, 28-30. 